\title{
Implementation on Solid Waste Reduction through 3R (NSWM Policy) and Elements to Close Gap between Policy and Contractors in Construction Industry in Penang
}

\author{
L. S. Ng, T. W. Seow, and K. C. Goh
}

\begin{abstract}
The construction industry is seriously contributing to waste disposal due to the rapid development of construction industry. Weaknesses in the implementation on solid waste reduction through $3 \mathrm{R}$ among contractors in the construction industry will cause unsustainable construction waste management. This has increased construction waste in landfills, especially island areas where limited of land for waste disposal activities. This paper aimed to study the implementation on solid waste reduction through 3R NSWM Policy among contractors in the construction industry in Penang, Malaysia and elements to close gap between policy and contractors. This paper conducted by the semi-structured interview, questionnaire survey and participant observation. The respondents consisted of officers Municipal Council and CIDB in Penang and 61 contractors registered under CIDB located in Penang. The results show that solid waste reduction through $3 R$ is currently ineffective and has limited implementation in the construction industry in Penang. Furthermore, most respondents revealed that law enforcement, implementation among contractors and awareness are the elements that appropriate to close gap between the policy and contractors. Construction waste should be managed through the $3 R$ as it is sustainable. Thus, all parties involved should be aware and emphasize the $3 R$ concept for reducing the construction waste disposal.
\end{abstract}

Index Terms-Policy implementation, construction waste, 3R, elements close gap.

\section{INTRODUCTION}

Solid waste reduction through $3 \mathrm{R}$ is thrust 1 in the National Solid Waste Management Policy. The 3R represents the concept in the categories of reduce, reuse and recycle [1]. The Solid Waste Management and Public Cleansing Act 2007 (Act 672) had been passed on July 17, 2007 and it had gazetted on August 30, 2007. The Act 672 gives the executive power to the federal government to take the responsibility for solid waste management and public cleansing [2]. The controlled solid waste including commercial solid waste, construction solid waste, household solid waste, industrial solid waste, institutional solid waste, imported solid waste, public solid waste and time to time solid waste [3].

Manuscript received September 5, 2014; revised December 11, 2014. This work was financially supported by the Ministry of Higher Education, Malaysia (KPT), Research and Innovation Centre, Universiti Tun Hussein Onn Malaysia (UTHM) under the Multi Disciplinary Research Grant Scheme (MDR) Grant No. V1316 and Postgraduate Incentive Research Grant (GIPS) No. VOT 1394.

L. S. Ng, T. W. Seow, and K. C. Goh are with the Faculty of Technology Management and Business, Universiti Tun Hussein Onn Malaysia, 86400 Parit Raja, Batu Pahat, Johor, Malaysia (e-mail: leeshan3122@gmail.com, tawee@uthm.edu.my, kaichen@uthm.edu.my).
Construction and demolition waste generated from construction industries include construction activities, renovation, civil construction, road construction, demolition activities, site cleaning and soil excavation [4]-[5].

Weaknesses in implementation of solid waste reduction through $3 \mathrm{R}$ among contractors in the construction industry will lead to unsustainable construction waste management. In fact, this situation has increased generation of construction waste in landfills, especially on islands where land is very limited for waste disposal activities to be carried out Reference [6] shows Malaysia is a country that is facing an increase in waste generation and the negative impacts associated with disposal. The rise in the number of building and infrastructure development projects has led to an increase in the generation of construction waste. Reference [7] shows that so far about 95 percent of the waste is directly disposed in landfills. This action will not only create environmental problems, but it also leads to unsustainable management. The main factor in the weak implementation of $3 R$ is the lack of a specific policy and focus on construction waste management, particularly the $3 \mathrm{R}$ approach.

Reference [8] shows that implementation of the policy will fail if the law and act are not mandatory and enforced. With reference to [9], the enforcement and implementation of $3 R$ practices are listed in Part X: Reduction and Recovery Controlled Solid Waste, which means that the persons who generate solid waste are required to reduce the amount of waste through 3R. However, reference [10] shows that Act 672 has not been enforced in Penang since1 September 2011. The Municipal Council only provides the landfill and disposal services but does not interfere in the process of on-site construction waste management [11]. This is because contractors are responsible for the task of managing the construction waste [12].

Besides that, construction waste has always been neglected in the effort to reduce waste sent to landfills because the focus is only on the reuse and recycling of domestic waste [13]. The approach of initiative "Cleaner, Greener Penang" aims to encourage people to minimize waste through $3 \mathrm{R}$ to stop the generation of waste in the future; however, this initiative has always only been enforced in the market and hawker stalls [14]. The problem of waste disposal in Penang is shortage of land because the disposal landfill requires a large piece of land [15]. The waste transfer center in Ampang Jajar had faced technical problems, which almost paralyzed the waste disposal process in Penang; this is because the transfer station could not accommodate the hundreds of tonnes of garbage and solid waste sent from Penang Island and Seberang Perai 
[16].

Thus, the elements to close the gap between policy and contractors should be stressed and emphasized to achieve sustainable construction waste management. Which include the elements of role of government, elements of law enforcement, elements of implementation among contractors, elements of awareness of the $3 \mathrm{R}$ policy in the construction industry and also the elements of technology and technique to reduce, reuse and recycle.

Role of government: The government should provide incentives to the contractors who apply $3 \mathrm{R}$ in construction waste management [17]. In an attempt to promote waste reduction, reuse and recycling, the Hong Kong government has implemented the Construction Waste Disposal Charging Scheme (CWDCS) to provide financial incentives for those who reduce construction and demolition waste and promote reuse and recycling [18]; in addition, charges are imposed on construction and demolition waste that require landfill [19].The government should provide guidance to the contractors for reducing construction waste [17] and set up an effective recycling company for various types of waste [20].

Law enforcement: The government should enact and implement relevant laws and acts to increase the awareness of $3 \mathrm{R}$ activities among contractors; in fact, even the awareness level of environmental and sustainable waste management is still low [21].Policy and legislation play a crucial role in the implementation of the 3R approach. Japan and South Korea enforced the law on recycling of construction waste and demolition waste management to encourage reduction of construction waste [11]. Besides that, the Singapore government prefers to adopt a top-down approach by using legislation and regulation to enforce the policy on solid waste management [22].

Implementation among contractors: Current waste disposal methods are not sustainable and the waste management hierarchy approach is believed to be a better method and should be applied. Contractors should practice the $3 \mathrm{R}$ approach: reduce, reuse and recycling of construction waste before disposal to landfill [23]. The concept of integrating waste management has been applied to reduce waste at the source where segregated source of waste is recovered through reuse and recycling [24]. Construction waste should be recycled as soon as possible and reused as much as possible to reduce the waste in construction sites [25].

Awareness of the $3 R$ policy in the construction industry: Education programs, training and awareness campaigns should be carried to encourage the contractors to practice the $3 \mathrm{R}$ approach in the construction industry to segregate and recycle waste as well as motivate them to efficiently manage construction waste [17].

Technology and technique to reduce, reuse and recycle: Inert waste consists of sand, bricks and concrete that can be used for land reclamation [26]. Architects and engineers can identify the major steel structure components that can be recycled [27]. The most common wood framework can be reused several times [28]. Besides that, the Industrialized Building System (IBS) encourages use in construction projects to reduce construction waste. This is because IBS components can reduce the quantity of waste from wood formwork, where IBS involves the prefabricated components and installation at the construction site [29].

This paper aims to study the implementation of solid waste reduction through 3R thrust 1 in the NSWM Policy among contractors in the construction industry in Penang, Malaysia and identify elements that can close the gap between policy and contractors. This paper involves respondents who consist of officers from Municipal Council in Penang, CIDB Penang and also 61 contractors registered as Grade G7, G6 and G5 under CIDB located in Butterworth, Bukit Mertajam and Georgetown in Penang, Malaysia.

\section{ReSEARCH METHODOLOGY}

The research methodology consists of semi-structured interview, questionnaire survey and participant observation. Semi-structure interview was done with officers working in Penang Island (MPPP) and Seberang Perai (MPSP) Municipal Council and Construction Industry Development Board (CIDB) Penang. Meanwhile, the questionnaires were distributed to the target respondent contractors. Based on the sample size in the table presented by Krecjie and Morgan [30], a sample size of 92 persons is required when the population is 123 persons. In this research, 61 respondents were selected randomly among contractors registered as Grade G7, G6 and G5 under CIDB located in Butterworth, Bukit Mertajam and Georgetown, Penang. The response rate for the contractors is 49.6 percent. According to [31], as a rule of thumb, a 30 per cent return is seen as fairly satisfactory and more than 50 per cent is good. Hence, the response rate for this research can be considered to be good. Besides that, participant observation also was done in the Jelutong Landfill, Ampang Jajar Waste Transfer Station and Pulau Burung Landfill in order to get an idea of the actual situation and collect the relevant information.

\section{RESULTS AND DISCUSSION}

Based on the method of interview, questionnaire survey and participant observation, the current practice of construction waste management and the effectiveness of implementation solid waste through 3R among the selected contractors in Penang, Malaysia and also the elements that close the gap between policy and contractors are discussed as follows.

\section{A. The Implementation of Solid Waste Reduction through \\ $3 R$ Thrust 1 in the NSWM Policy among Contractors in the Construction Industry in Penang, Malaysia}

The findings of implementation of solid waste reduction through 3R thrust 1 in NSWM Policy among contractors in the construction industry in Penang, Malaysia were obtained through questionnaire survey, interview and participant observation. Based on the results of survey questionnaire as shown in Table I, more than half of the respondents applied the $3 \mathrm{R}$ approach to manage their construction waste, which is 67.2 percent (41 persons); meanwhile, 33.8 percent (20 persons) of the respondents disposed construction waste directly. 
The results indicate that the $3 \mathrm{R}$ practice is prevalent among contractors in Penang. However, the percentage of construction waste that is managed through $3 \mathrm{R}$ practice is still very low. Most of the contractors only manage a small percentage of their construction waste through $3 \mathrm{R}$ practice. In fact, only 3 respondents managed 60 percent, 70 percent and 50 percent of construction waste through $3 \mathrm{R}$ practice respectively. One reason for this situation is that contractors only reuse and recycle common materials like steel and wood, which make up very little of the overall amount of construction waste.

TABLE I: 3R PRActice and Percentage of Waste Manage through

\begin{tabular}{|c|c|c|}
\hline $\begin{array}{l}\text { Manage construction } \\
\text { waste through } 3 R\end{array}$ & $\begin{array}{c}\text { Percentage of } \\
\text { construction waste }\end{array}$ & $\begin{array}{c}\text { Percents of } \\
\text { contractors } \\
\text { (Number) }\end{array}$ \\
\hline No & $\begin{array}{l}0 \% \text { (No. Disposed } \\
\text { directly) }\end{array}$ & $\begin{array}{c}33.8 \% \\
\text { (20 person) }\end{array}$ \\
\hline \multirow{8}{*}{ Yes } & $10 \%$ & $\begin{array}{c}18.0 \% \\
\text { (11 person) }\end{array}$ \\
\hline & $20 \%$ & $\begin{array}{c}21.3 \% \\
\text { (13 person) }\end{array}$ \\
\hline & $30 \%$ & $\begin{array}{c}8.2 \% \\
\text { (5 person) }\end{array}$ \\
\hline & $40 \%$ & $\begin{array}{c}8.2 \% \\
\text { (5 person) }\end{array}$ \\
\hline & $50 \%$ & $\begin{array}{c}1.6 \% \\
\text { (1 person) }\end{array}$ \\
\hline & $60 \%$ & $\begin{array}{c}4.9 \% \\
\text { (3 person) }\end{array}$ \\
\hline & $70 \%$ & $\begin{array}{c}4.9 \% \\
\text { (3 person) }\end{array}$ \\
\hline & Total (Yes) & $\begin{array}{c}67.2 \% \\
\text { (41 person) }\end{array}$ \\
\hline \multicolumn{3}{|c|}{ Total: $100 \%$ (61 person) } \\
\hline
\end{tabular}

Besides that, in the questionnaire, respondents were asked to rate the effectiveness of implementation of the solid waste reduction through $3 R$ in reducing the waste disposed at the landfill in Penang; the results are shown in Fig. 1. There are 5 levels to evaluate the effectiveness of implementation of the solid waste reduction through $3 \mathrm{R}$ among contractors to reduce the waste disposed at the landfill in Penang. Based on the results, 39.3 percent of the respondents found the $3 R$ approach to be moderately effective and 36.1 percent believed it was less effective in helping to reduce solid waste. Only a minority of the respondents mentioned that the implementation was very effective and effective, with 3.3 percent and 21.3 percent respectively. Hence, it can be said that the majority of the respondents found the $3 \mathrm{R}$ approach to be not very effective.

The findings of the interview provide another viewpoint concerning the $3 \mathrm{R}$ approach, and its implementation was also found to be not very efficient in the construction industry in Penang. The MPSP revealed that the effectiveness of implementation was only 30 percent, while the CIDB Penang said that it was about 10 percent. MPPP mentioned that solid waste reduction through $3 \mathrm{R}$ is hard and difficult to implement in the construction industry in Penang. This is due to the behavior and attitude of the contractors and because not all construction waste can be managed through $3 \mathrm{R}$ practice. An example would be the situation in Jelutong Landfill, Penang where the surface of the waste disposed is approximately 48 meters from the sea level beside the landfill.

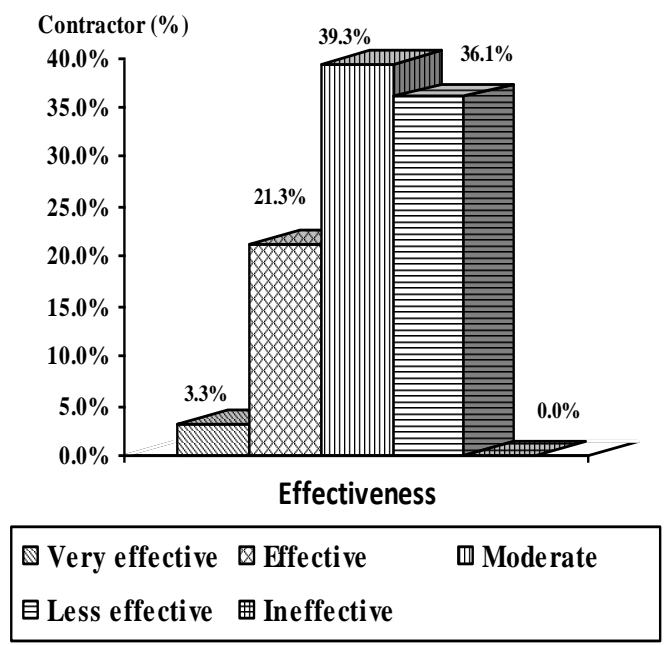

Fig. 1. Effectiveness of implementation of solid waste reduction through $3 \mathrm{R}$ to reduce the waste disposed at landfill in Penang.

\section{B. Findings of Participant Observation}

Participant observation carried out at three locations which are Jelutong Landfill, Ampang Jajar Transfer Station and Pulau Burung Landfill. The findings of participant observation were explained as below.

\section{Jelutong Landfill}

Jelutong Landfill is located in Penang Island. The observation at Jelutong Landfill involved interviews with the Penang Island Municipal Council officers to obtain information. Jelutong Landfill has been operating since 1992 and it is managed by the Engineering Department, Penang Island Municipal Council. The landfill area is around 53 acres, which is around $22000 \mathrm{~m}^{2}$. However, the area that encroaches on the expressway has been partially closed since 2012. All the private contractors and contractors from the Municipal Services Department of MPPP can send the waste there. However, private contractors need apply for the entry permit to Jelutong Landfill and are required to pay a fee for the entry permit.

Jelutong Landfill has only one level of landfill; open dumping ispracticed in Jelutong Landfill where the waste can only be disposed and leveled by a bulldozer. The landfill does not utilize advanced technology, and there is no waste treatment and waste management in place. When the waste reaches the maximum height level, the surface will be covered by soil, which is usually clay. The disposal activities are very limited and it can be seen that the waste surface is estimated at 38 meters high above the sea level beside the landfill. Almost construction waste are sent to this landfill such as soil, sand, rock, pile, bricks, concrete, hardcore and many others. Sometimes, the management will reuse and recycle some construction waste for landfill road maintenance at the landfill 
and to cover the surface of waste.

\section{Ampang Jajar Waste Transfer Station}

Ampang Jajar Waste Transfer Station is located in Seberang Perai, Penang. Ampang Jajar Waste Transfer Station began operations in 2004 and was managed by Idaman Bersih Sdn. Bhd. to manage, transfer and transport domestic waste. In July 2011, Eurasia Express Sdn Bhd (EESB) took over the operations of Ampang Jajar Waste Transfer Station. Eurasia Express Sdn Bhd plays the role of a solution provider and operates the transfer station for MPPP and MPSP Penang. In 2017, it is expected that the transfer station will have separate operations in Penang Island and Ampang Jajar.

Ampang Jajar Waste Transfer Station operates 24 hours a day throughout the year. MPSP will send the waste in the daytime while MPPP will send the waste to Ampang Jajar Transfer Station at night. Construction waste does not have weighed data records because construction waste is only directly dumped at a site behind Ampang Jajar Waste Transfer Station. Besides that, a buy-back center has also been established for buying back recyclable item from collectors under the municipal council at market price.

Fig. 2 shows the main operations and work flow at Ampang Jajar Waste Transfer Station, which are summarized as below:

- Receive and weigh the waste sent.

- Discharge the waste into silo from lorry or truck.

- Vertical compaction applied to compress the waste into the silo.

- The station truck will transport the full silo to prime mover.

- EESB use the enzymes sprinkler system at the waste discharging area for getting rid of dust and odor.

- Leachate treatment in the transfer station.

- Every double silo trailer (prime mover) is able to carry 2 silos for every trip to transfer the waste to Pulau Burung Landfill. Each silo can load a maximum of 15 tonnes of waste.

- Double silo trailer will transport the full silo to Pulau Burung Landfill. GPS system is applied to detect the location of silo trailer.

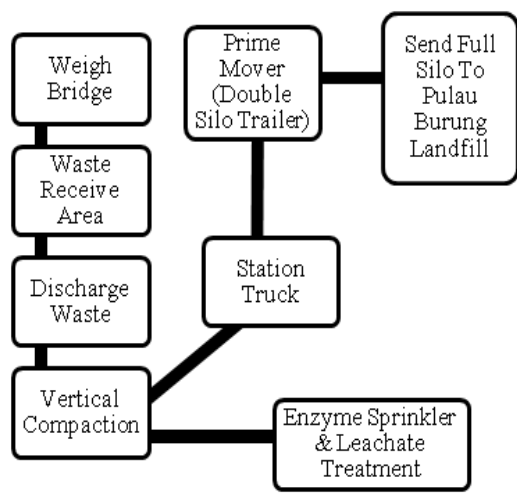

Fig. 2. Main operation and work flow in Ampang Jajar Transfer Station.

\section{E. Pulau Burung Landfill}

Pulau Burung landfill is located in Seberang Perai, Penang. Pulau Burung Landfill started operating in 2001. PLB Terang Sdn. Bhd. was awarded the license to operate and maintain Pulau Burung Landfill for 20 years since 2012. There are 3 phases in Pulau Burung Landfill where phase 1 is the final closer landfill while phase 2 is the current landfill area, administration platform, buy-back center and E-co Park. Phase 3 has been proposed to be used for construction of MRF (Materials Recovery Facility). The landfill operates 24 hours a day throughout the year for MPSP and MPPP. The waste disposed in landfill is approximately 25 to 30 meters high.

There is no official weight data recorded for construction waste. This is because construction waste is sometimes mixed together with domestic waste, and hence also considered as domestic waste. Besides that, some construction waste is dumped illegally at the roadside and inside palm oil plantations along the way to Pulau Burung Landfill. Waste landfill will be leveled and compacted before it is covered with soil. Red soil is used daily, and around 40,000 tonnes per month to reduce leachate and odor. Scavengers in the landfill are required to sell the recyclable items to the buy-back center in the landfill at market price. The administration provides scavengers with insurance and safety and health protection in the landfill.

\section{F. Elements that Close the Gap between Policy and Contractors}

The findings of elements that close the gap between policy and contractors were obtained through questionnaire survey and interview. Table II shows the mean score analysis for the 5-point Likert scale. According to [32], the 5-point Likert scale is used to help respondents indicate their level of agreement. Based on Table II, the mean score of 0.00 to 1.50 indicates strongly disagree, 1.51 to 2.50 indicates disagree, 2.51 to 3.50 indicates moderate, 3.51 to 4.50 indicates agree and 4.51 to 5.00 indicates strongly agree.

TABLE II: MEAN SCORE ANALYSE

\begin{tabular}{|c|c|}
\hline Mean score & Level of agreement \\
\hline 0.00 to 1.50 & Strongly disagree \\
\hline 1.51 to 2.50 & Disagree \\
\hline 2.51 to 3.50 & Moderate \\
\hline 3.51 to 450 & Agree \\
\hline 4.51 to 5.00 & Strongly agree \\
\hline
\end{tabular}

For the result analysis, Table III shows the level of agreement pertaining to elements that close the gap between policy and contractors. Overall, the respondents agreed with the elements of the role of government in providing incentives, Construction Waste Disposal Charging Scheme (CWDCS), the guidelines and the establishment of a recycling company for construction waste, with the mean score of 3.52 . Compared with the interview results, all the officers interviewed also noted that the elements of the role of the government will be very effective in motivating contractors. Moreover, contractors also can benefit at the same time. However, these elements are still weak in the current construction industry.

Besides that, most of the respondents agreed with the element of law enforcement using a top-down approach in legislation and establishing policies and law for the 
construction industry, with the mean score of 3.71 . Meanwhile, MPSP and CIDB Penang mentioned that the $3 \mathrm{R}$ policy cannot to be enforced and be made mandatory without providing contractors with guidance and knowledge about the $3 R$ practice. This is because the $3 R$ policy is still new in the construction industry. Enforcement can only be carried out after an education period where the contractors must practice $3 \mathrm{R}$ in construction waste management. However, MPPP revealed that element of law enforcement is not suitable to be implemented in the construction industry. In their opinion, contractors can be encouraged to practice $3 \mathrm{R}$, but it cannot be made mandatory. Instead, it is more crucial to have law enforcement to deal with issues of illegal construction waste management.

In addition, the respondents agreed with the element of implementation among contractors using waste management hierarchy approach and integration of waste management concept, with the mean score of 3.72. The officers of MPPP and CIDB Penang who were interviewed stated that this element is appropriate and its implementation will be effective. In addition, they also mentioned that some of the contractors have actually gone through this element indirectly when managing some types of construction waste. Meanwhile, MPSP officers described this element as being poorly and not fully implemented; however, it can still be emphasized during the course attended by contractors.

TABLE III: ELEMENTS ThAT Close THE GAP BETWEEN POLICY AND

\begin{tabular}{|l|c|c|c|}
\hline & $\begin{array}{c}\text { Mean } \\
\text { score }\end{array}$ & $\begin{array}{c}\text { Standard } \\
\text { deviation }\end{array}$ & $\begin{array}{l}\text { Level of } \\
\text { agreement }\end{array}$ \\
\hline Role of government & 3.52 & 0.51 & Agree \\
\hline Law enforcement & 3.71 & 0.37 & Agree \\
\hline $\begin{array}{l}\text { Implementation among } \\
\text { contractors }\end{array}$ & 3.72 & 0.40 & Agree \\
\hline $\begin{array}{l}\text { Awareness 3R of the } \\
\text { policy in the construction } \\
\text { industry }\end{array}$ & 3.74 & 0.39 & Agree \\
\hline $\begin{array}{l}\text { Technology and } \\
\text { technique to reduce, reuse } \\
\text { and recycle }\end{array}$ & 3.36 & 0.54 & Moderate \\
\hline
\end{tabular}

Moreover, the analysis of results show that respondent agree with the element of $3 \mathrm{R}$ policy in the construction industry in order to conduct educational programs and awareness campaigns to create awareness of $3 \mathrm{R}$ in the construction industry, with the mean score of 3.74. Compared with findings of interview, all the officers mentioned that this element is effective. CIDB Penang and Campaign Unit (Department of Urban Services, Public Health \& Licensing) has an important role in using the media and courses to deliver information and knowledge to raise the level of awareness of $3 \mathrm{R}$ practices among contractors concerning construction waste management in Penang.

Based on the analysis, respondents revealed that elements of technology and technique to reduce, reuse and recycle are moderate to close the gap between policy and contractors, where the mean score is 3.36. The findings of interview revealed that this element can be implemented and technology such as IBS already exists. However, technology IBS cannot be used for all projects; it can only be used for high-level projects and costly projects. This is because the use of IBS is very costly, and it requires experts to operate it. Hence, those contractors involved in small or moderate projects will normally use conventional methods. Besides that, the technique to reduce, reuse and recycle construction waste can be applied by those contractors who possess the knowledge and skill to use it. However, the contractors also have to bear the cost of machinery and equipment used at the same time. This may be the reason why respondents moderately agreed with this element compared with the others.

TABLE IV: CORRELATION SIZE REPRESENT THE STRENGTH CORRELATION

\begin{tabular}{|c|c|}
\hline Correlation size & $\begin{array}{c}\text { Correlation } \\
\text { strength }\end{array}$ \\
\hline 0.91 to 1.00 or -0.91 to -1.00 & Very strong \\
\hline 0.71 to 0.90 or -0.71 to -0.90 & Strong \\
\hline 0.51 to 0.70 or -0.51 to -0.70 & Moderate \\
\hline 0.31 to 0.50 or -0.31 to -0.50 & Weak \\
\hline 0.01 to 0.30 or -0.01 to -0.30 & Very weak \\
\hline 0.00 & No relation \\
\hline
\end{tabular}

TABLE V: CORRELATION MATRIX FOR ELEMENTS THAT Close THE GAP BETWEEN POLICY AND CONTRACTORS

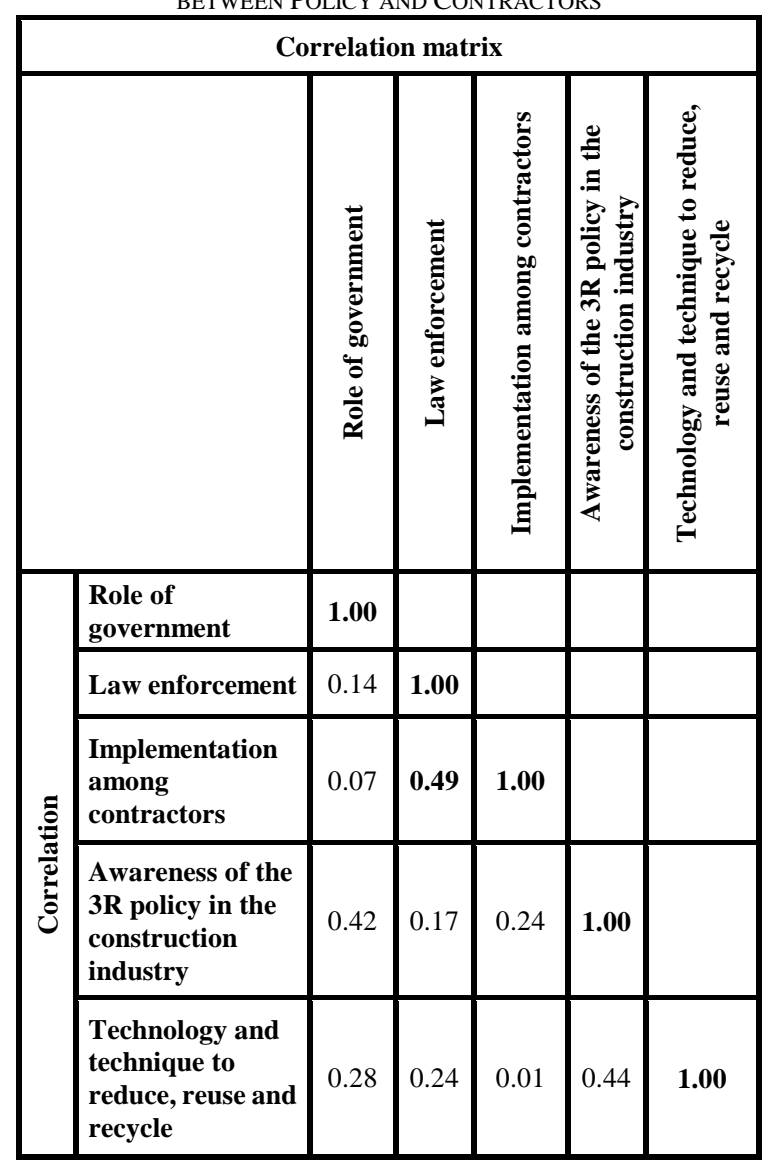

Besides that, the findings of the elements that close the gap between policy and contractors based on the questionnaire survey were also analyzed using correlation matrix. The purpose of correlation matrix is to establish the relationship of each variable with all other variables. Correlation values can vary between -1.00 to 1.00 . A correlation value of zero represents no relationship between the two variables. Correlation of each variable by itself is always 1.00 [33]. 
Table IV shows the correlation size and the corresponding strength of the correlation [34].

Based on the results shown in Table V, the elements have only three weak correlations while the others have very weak correlations with other elements. The strength of correlation between the element of implementation among contractors and element of law enforcement was weak, where the correlation size is 0.49 . The strength of correlation between the element of role of government and the element of awareness of the $3 \mathrm{R}$ policy in the construction industry was weak, where the correlation size is 0.42 . Meanwhile, the correlation between the element of awareness of the $3 \mathrm{R}$ policy in the construction industry and the element of technology and technique to reduce, reuse and recycle was weak, where the correlation size is 0.44 . The result analysis of correlation matrix revealed the element of implementation among contractors and the element of law enforcement have the strongest relationship compared with the other elements. The relationship between these two elements implies that law enforcement will significantly affect the implementation among contractors.

\section{RECOMMENDATIONS}

All the parties involved have to put in effort to overcome the challenges and practice $3 \mathrm{R}$ in order to reduce construction waste disposal in landfills. A top-down approach is suggested to facilitate implementation of $3 \mathrm{R}$. This approach is a style of autocratic and hierarchical decision-making, where organizational and leadership changes in the strategy or plan are established by one or several top managers. Then, the results, changes, strategies and policies will be spread to the bottom of organization structure later. The bottom level in the hierarchy is bound by the decision made by top management [35].

Moreover, using a top-down approach is an initiative to reduce waste sent to landfills and increase the stability of the disposed landfills. This should be handled through a top-down approach with intervention of relevant policies and acts [36]. This approach should be applied to the elements discussed in order to close the gap between policy and contractors for reducing construction waste through $3 \mathrm{R}$ to achieve sustainable construction waste management. Therefore, the government is responsible for implementing a top-down approach to enforce the laws and policies related to $3 \mathrm{R}$ practice in the construction waste management by making it mandatory for contractors to manage construction waste through $3 \mathrm{R}$ practice.

Moreover, law enforcement can ensure consistent monitoring of the practice of construction waste management at the site among contractors. Contractors will practice $3 \mathrm{R}$ during construction waste management to avoid summons and getting blacklisted. By using a top-down approach, 3R practice can be embedded in the contract of construction project and be made as one of the requirements for contractor registration with CIDB. At the same time, the government and solid waste department should provide incentives and subsidies, guidelines, standards and quality control to the contractors.

Besides that, CIDB also needs to be proactive in organizing talks, courses, awareness campaigns, and education and training programs among contractors. This is an effective channel to communicate and deliver information and knowledge about $3 \mathrm{R}$ and to motivate the contractors to practice 3R. Meanwhile, the use of technology can also be promoted among contractors those involved in the large construction projects. Hence, applying a top-down approach will improve the implementation of solid waste reduction through $3 \mathrm{R}$ among contractors in the construction industry and increase the awareness level of the $3 \mathrm{R}$ concept among contractors and achieve sustainable construction waste management.

\section{CONCLUSION}

The rapid development of the construction industry in Penang, Malaysia had led to large quantities of construction waste, which these has increased the quantity of waste disposed in landfills. Currently, there are only two landfills operating in Penang, Malaysia. These both landfills are unable to accommodate the amount of waste disposed in the long term. Moreover, Penang is an island area, and land is scarce to build new landfills. This paper has discussed the implementation of solid waste reduction through $3 \mathrm{R}$ among contractors in the construction industry in Penang, Malaysia and the elements that close the gap between policy and contractor.

Many researchers have found that several types of construction waste can be potentially reused or recycled. Therefore, construction waste should be managed through the $3 \mathrm{R}$ approach as it is sustainable, and contractors should only send the useless construction waste to landfills. Thus, contractors, Municipal Council, government and all parties involved should be aware and focus on the $3 \mathrm{R}$ concept and practices to manage the construction waste in Penang. In addition, a top-down approach should be applied in order to improve the implementation of solid waste reduction through $3 \mathrm{R}$ among contractors and reduce the construction waste dispose in landfill to achieve sustainable construction waste management.

\section{ACKNOWLEDGMENT}

This paper was made possible through the contribution and help from the important parties in this study. The authors would like to thank the Ministry of Higher Education, Malaysia (KPT), Research and Innovation Centre, Universiti Tun Hussein Onn Malaysia (UTHM), Faculty Technology Management and Business (FPTP) UTHM, Centre for Graduates Studies (PPS) UTHM for supporting and giving helpful and guidance. Besides that, the authors also would like to thank all the respondent contractors, Penang Island and Seberang Perai Municipal Council and CIDB Penang for providing useful data and information that input to carry out the study in this paper.

\section{REFERENCES}

[1] National Solid Waste Management Department. (April 2012). National Solid Waste Management Policy. [Online]. Available: http://www.kpkt.gov.my/jpspn/main.php?Content=articles\&ArticleID $=64 \& \mathrm{IID}=$ 
[2] National Solid Waste Management Department. (April 2013). History of Department Establishment. [Online]. Available: http://www.kpkt.gov.my/jpspn_2013/main.php?Content=vertsections $\&$ SubVertSectionID=166\&VertSectionID=1\&CurLocation=51\&IID= $\&$ Page $=1$

[3] National Solid Waste Management Department. (March 2013). Categories of controlled solid waste. [Online]. Available: http://www.kpkt.gov.my/jpspn_en_2013/main.php?Content=articles \&ArticleID $=41 \& \mathrm{IID}=$

[4] L. Y. Shen, W. V. Y. Tam, C. V. Tam, and D. Drew, "Mapping approach for examining waste management on construction sites," Journal of Construction Engineering and Management., vol, 130, no. 4, pp. 472-481, 2004.

[5] J. F. Huang, Q. B. Liang, H. Wang, S. Y. Xu, L. S. Zhang, and Y. Xing, "Comprehensive recycling of construction waste," Applied Mechanics and Materials., vol. 117-119, pp. 385-389, 2011.

[6] R. A. Begum, C. Siwar, J. J. Pereira, and A. H. Jaafar, "Factors and values of willingness to pay for improved construction waste management - A perspective of Malaysian contractors," Waste Management, vol. 27, issue 12, pp. 1902-1909, 2007.

[7] P. Agamuthu, S. Chenayah, F. S. Hamid, and D. Victor, "3R related polices for sustainable waste management in Malaysia," in Proc. Conferences of Innovation and Sustainability Transitions in Asia, Kuala Lumpur, Malaysia, 2011, p. 135.

[8] Z. Wei and S. Rotter, "The current situation of construction \& demolition waste management in China," in Proc. The 2nd International Conference on Bioinformatics and Biomedical Engineering, 2008, pp. 4747-4750.

[9] P. Agamuthu, S. H. Fauziah, and K. Khidzir, "Evolution of solid waste management in Malaysia: Impacts and implications of the solid waste bill, 2007," Material Cycles and Waste Management, vol. 11, issue 2, pp. 96-103, 2009.

[10] National Solid Waste Management Department. (April 2013d). Frequently Asked Questions JPSPN. [Online]. Available: http://mjpspn.kpkt.gov.my/index.php/page/view/227

[11] V. Nitivattananon and G. Borongan. (2008). Report on reduce, reuse and recycle (3r) practices in construction and demolition waste management in Asia. [Online]. Available: http://www.3rkh.net/3rkh/files/3RKH_C\&D_waste_FinalReport.pdf

[12] Penang Hijau Bersih. (2010). Appropriate method (Kaedah pendekatan). [Online]. Available: http://www.cleanergreenerpenang.com/bm/how.html

[13] L. S. Ng, T. W. Seow, and K. C. Goh, "The Practice of construction waste management in Penang Island," in Proc. 1st FPTP Postgraduate Seminar toward Sustainable Management, Batu Pahat, Johor, UTHM, 2013.

[14] T. W Seow and A. H. Mohamad. (2007). Construction Waste Management at Construction Site. [Online]. Available: http://sssums.files.wordpress.com/2007/09/pengurusan-sisa-pembina an-di-tapak-bina.pdf

[15] L. S. Ng, T. W. Seow, and K. C. Goh, "Theoretical framework for sustainable in construction waste management toward $3 \mathrm{R}$ pratice in Penang," in Proc. 2nd International Conference on Technology Management, Business and Entrepreneurship, Melacca, 2013, pp. 71-81.

[16] A. M. Sapidin. (July 7, 2011). Waste disposal process almost paralyzed in Penang. Utusan Online. [Online]. Available: http://utusan.com.my/utusan/info.asp?y=2011\&dt=0707\&pub=Utusa n_Malaysia\&sec=Dalam_Negeri\&pg=dn_13.htm

[17] R. A. Begum, C. Siwar, J. J. Pereira, and A. H. Jaafar, "Implementation of waste management and minimisation in the construction industry of Malaysia," Resources, Concervation and Recycling, vol. 51, issue 1, pp. 190-202, 2007.

[18] C. S. Poon, A. T. W. Yu, A. Wong, and R. Yip, "Quantifying the impact of construction waste charging scheme on construction waste management in Hong Kong," Construction Engineering and Management, vol. 139, issue 5, pp. 466-479, 2013.

[19] A. T. W. Yu, C. S. Poon, A. Wong, R. Yip, and L. Jaillon, "Impact of construction waste disposal charging scheme on work practices at construction sites in Hong Kong," Waste Management, vol. 33, issue 1, pp. 138-146, 2013.

[20] S. M. S. Musa, H. Shafii, and S. N. S. M. Zubir, "Potential of recycling in construction industry: Case study in Batu Pahat, Johor. (Potensi Kitar Semula Dalam Industri Pembinaan: Kajian Kes Daerah Batu Pahat, Johor)," in Proc. The 3rd Malaysian Technical Universities Conference on Engineering and Technology (MUCEET2009), Kuantan, Pahang, 2009, pp. 553-559.
[21] E. Papargyropoulou, C. Preece, R. Padfield, and A. A. Abdullah, "Sustainable construction waste management in Malaysia: A contractor's perspective," in Proc. the MISE 2011 International Conference on Management and Innovation for a Sustainable Built Environment, 2011

[22] Y. Y. Ho. (2002). Recycling as a sustainable waste management strategy for Singapore: An investigation to find ways to promote Singaporean's household waste recycling behaviour. Lund University. [Online]. Available: http://www.lumes.lu.se/database/alumni/01.02/theses/ho_yanyin.pdf

[23] S. Nagapan, I. A. Rahman, and A. Asmi, "Construction Waste Management: Malaysian Perspective," in Proc. The International Conference on Civil and Environmental Engineering Sustainability 2012 (IConCEES 2012), Johor Bahru, Malaysia, 2012.

[24] U. N. Ngoc and H. Schnitzer, "Sustainable solutions for solid waste management in southeast asian countries," Waste Management, vol. 29, issue 6, pp. 1982-1995, 2009.

[25] Y. P. Hu, "Minimization Management of Construction Waste," in Proc. The International Symposium on Water Resource and Environmental Protection (ISWREP 2011), 2011, pp. 2769-2772.

[26] C. S. Poon, T. W. A. Yu, and L. H. Ng, "On-site sorting of construction and demolition waste in Hong Kong," Resources, Conservation and Recycling, vol. 32, no. 2, pp. 157-172, 2001.

[27] G. Winkler, Recycling Construction \& Demolition Waste: A LEED-Based Toolkit, USA: McGraw-Hill, 2010, p. 19.

[28] V. W. Y. Tam, "Rate of reusable and recyclable waste in construction," in Proc. Second International Conference on Sustainable Construction Materials and Technologies, Italy, 2010, pp. 329-340.

[29] CIDB. (2012). IBS. Library CIDB Malaysia. [Online]. Available: https://www.cidb.gov.my/cidbweb/index.php?option=com_content\& view $=$ article\&id $=35 \&$ Itemid $=209 \&$ lang $=$ en

[30] R. V. Krejcie and D. W. Morgan, "Determining sample size for researching activities," Educational and Psychological Measurement, vol. 30 , issue $608,1970$.

[31] B. Gillham, The Research Interview, London: Continuum, 2000, p. 14.

[32] B. B. Bahril and W. Razzaly, Assessment Framework for "Recognition of Prior Learning- PLTV" in Malaysia, 2012.

[33] D. Cramer, Advanced Quantitative Data Analysis, USA: Open University Press, 2003, p. 15.

[34] Y. P. Chua, "Research method and statistic: research method," Book 2 , Malaysia: McGraw Hill, 2006, p. 167.

[35] MBA Brief. (2013). Top-down Approach. [Online]. Available: http://www.mbabrief.com/what_is_top_down_approach.asp

[36] K. Joseph and R. Nagendran. (2007). Top down and bottom up approach for sustainability of waste management in developing countries. [Online]. pp. 1-9. Available: http://www.swlf.ait.ac.th/UpdData/International/NRIs/Top\%20to\%20 down\%20approach.pdf

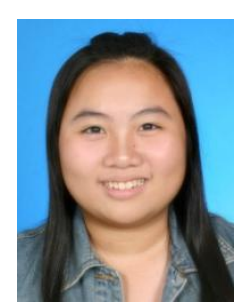

L. S. Ng was born in Penang, Malaysia on January 16, 1989. She received her bachelor of technology management degree in constructions with honours from Universiti Tun Hussein Onn Malaysia (UTHM) in 2013 and she had also completed industrial training as a trainee in GHL Construction Sdn. Bhd. in Penang for 10 weeks in 2012 to fulfill the qualify for graduation of UTHM. She is currently a full time master student of science in technology management in Faculty of Technology Management and Business, UTHM. During the study, she received the sponsorship for the research and has been a research assistant under the Postgraduate Incentive Research Grant (GIPS) No. VOT 1394. Her research interests are construction waste management and environmental.

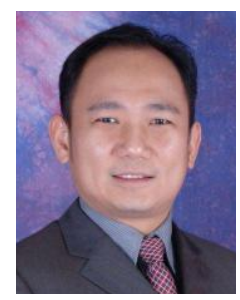

T. W. Seow was born in Johor, Malaysia on January 12, 1972, who received his B. Art degree in geography in 1998, master degree in environmental management in 1999 and Ph.D degree in environmental management in 2009 from Universiti Kebangsaan Malaysia (UKM).

He was a lecturer from 2002 to 2009 and senior lecturer from 2009 to 2012 in Universiti Tun Hussein Onn Malaysia (UTHM). Since 2013 he has been an associate professor at Faculty Technology Management and Business, UTHM

Associate professor Dr. Seow is a member of Geography Association of 
Malaysia and World Academic - Industry Research Collaboration organization. He is also a committee member of Committee Formulating University and College Act 1971, Ministry of Higher Education Malaysia from 16 Dec 2011 to 31 Mac 2012, and Environmental Management Association of Malaysia and Secretary of Asia Conference on Real Estate 2011 (ACRE 2011), UTHM. He is also the International Advisory Committee for International Trend in Engineering and Technological Sciences, 2014. He was the MQA Auditor in Environmental Management Field, Ministry of Education from 2014 to 2017, Conference General Chair in International Conference on Business Management and Information Technology 2014, Malaysia.

His interest and area expertise is in environmental management, socioeconomic, solid waste management, sustainability, safety and health, sustainable construction and management

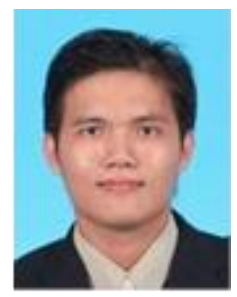

K. C. Goh was born in Sarawak, Malaysia on November 4, 1983, who received his bachelor of science (Hons) in construction in 2005 and master of science degree in construction management in 2006 from Universiti Teknologi Malaysia. He also received his doctor of philosophy degree in built environment and engineering from Queensland University of Technology, Australia.

He was a cadet quantity surveyor in Malaysia from 2002 to 2005 and assistant schedule planner in Singapore from 2006 to 2007. He was a tutor with Universiti Tun Hussien Onn Malaysia (UTHM) from 2007 to 2011. Since 2011 he has been the senior lecturer, laboratory chief and head of Research Cluster (Construction Management) of Faculty Technology Management and Business, UTHM.

Dr Goh is an accredited facilitator of Green Building Index (GBI)
Malaysia since 2012. He was one of the committee members of Asian Conference on Real Estate 2011 (ACRE 2011), Johor, Malaysia and the 2nd International Conference on Mechanical Engineering, Materials Science and Civil Engineering (ICMEMSCE 2013), Beijing, China. He also as an academic reviewer in Journal of Infrastructure Systems, American Society of Civil Engineers (ASCE), ISSN: 1076-0342 eISSN: 1943-555X, and InCIEC 2013, International Civil and Infrastructure Engineering Conference, 2013, Kuching, Malaysia, and CHUSER 2014 IEEE Colloquium on Humanities, Science and Engineering, 2014, Penang Malaysia. He has been a session chair in Asian Conference on Real Estate 2011 (ACRE 2011), Johor, Malaysia and International Conference on Engineering, Applied Sciences, and Technology, Bangkok, Thailand, 2012. His interest and area expertise is in sustainability infrastructure management, sustainability, sustainable construction, decision support modeling, renewable-energy management and construction management. 